\title{
Relacja między czynnościami i dążnościami ludzkimi a wartościami według Floriana Znanieckiego, czyli jak badać teksty kultury
}

DOl: 10.19195/2083-7763.7.14

\author{
To, co wiemy na temat rzeczywistości, \\ wiemy jedynie przez doświadczenie jej \\ i czynne myślenie o niej [...] (Znaniecki 2008, s. 65)
}

\section{Wprowadzenie}

W socjologii empirycznej obserwujemy stosunkowo małe zainteresowanie socjologią sztuki oraz działalnością artystyczną. Można się zastanawiać, jakie są tego przyczyny. Jedną z nich na pewno jest ciągle jeszcze przeważająca większość badań w socjologii polskiej, która dotyczy problemów związanych ze strukturą społeczną i wychodzi z założeń socjologii normatywnej, inaczej nazywaną socjologią strukturalną, traktującą człowieka jako jednostkę biernie podległą mechanizmom społecznym. Wystarczy przyjrzeć się tematom podejmowanym na Zjazdach PTS-u, aby przekonać się o prawdziwości tego stwierdzenia. Działalność artystyczna sama w sobie, jako twórcza, nie daje się analizować w ten sposób, co więcej, pokazuje, że rzeczywistość społeczna nie do końca funkcjonuje jak mechanicznie skonstruowany program komputerowy, któremu wystarczy napisać określone zadanie, i który da z góry przewidzianą odpowiedź. A nawet jeżeli to dotyczy części społeczeństwa socjalizowanego w taki sposób, żeby łatwo się nim manipulowało, to artyści ciągle jeszcze potrafią się z tego mechanicyzmu wyłamać. 


\section{Założenia teoretyczne}

Gdy przyjrzymy się bliżej socjologii Znanieckiego, to wyraźnie zauważalna jest myśl, iż system społeczny, aby przetrwać, potrzebuje mechanizmów, które zabezpieczają jego trwanie, oraz innych mechanizmów, umożliwiających jego zmianę. W tym sensie w jego dziełach można odnaleźć połączenie elementów późniejszej socjologii interpretatywnej z tradycyjną socjologią strukturalną. Jednak struktura rozumiana jest jako efekt komunikacji między jednostkami, ponieważ socjologia, według Znanieckiego, jest

„nauką o jednej specjalnej dziedzinie wartości i czynności ludzkich”, a nie o kulturze jako takiej; jest nauką o interakcji społecznej, a nie nauką o społeczeństwie w znaczeniu, w jakim myśleli o nim twórcy socjologii i większość socjologów współczesnych. Znaniecki stwierdza „wydaje się, że społeczeństwo, w znaczeniu konkretnej zbiorowości ludzkiej, rozpatrywanej w całokształcie swego życia kulturalnego, nie może być przedmiotem żadnego systematycznego i wyjaśniającego ujęcia" (Szacki 1986, s. 114).

Biorąc pod uwagę paradygmatyczny stosunek do nauki, moglibyśmy powiedzieć, że ciągle bardziej popularna w polskim środowisku naukowym jest socjologia normatywna, która kwestionuje podejście interpretatywne. Jak zauważa R. Boudon, główną cechą socjologii strukturalnej, gdyż tak ją możemy również nazywać, jest przekonanie, że „struktury społeczne są wystarczająco silne, by determinować jednostkę w taki sposób, iż można ją uznać za prostą zabawkę owych struktur" (2009, s. 3). Według tego francuskiego socjologa stanowisko takie możemy nazwać socjologizmem, czyli pewnym ideologicznym uproszczeniem, które nie spełnia podstawowych kryteriów naukowości. Na czym polega, według R. Boudona, socjologizm w praktyce? Potocznie moglibyśmy powiedzieć, że na wypowiedzeniu odpowiedzi przed zadaniem pytania. Francuski socjolog podaje następnie przykład, jak wygląda typowa analiza, np. zagadnienia ruchliwości społecznej. Polega to na tym, że

mamy większe szanse na to, by znaleźć się w klasie wyższej, jeśli z niej pochodzimy. [...] Jednak w obserwacji pominie się fakt, że gdy owa obserwacja odnosić się będzie do t y c h s a m y c h danych, że jeśli wywodzimy się z klasy wyższej, to mamy duże szanse na to, by w niej nie pozostać (Boudon 2009, s. 4).

\section{Założenia metodologiczne}

Niezmiernie ważną kwestią dla Znanieckiego jest obiektywność badań, nazywana czasami intersubiektywnością. Według niego taką obiektywność gwarantuje stosowanie w praktyce współczynnika humanistycznego. Polega to na dotarciu do faktów kulturowych (materiału empirycznego, np. tekstu literackiego) w taki sposób, aby odtworzyć, jak owe fakty kulturowe zostały doświadczone oraz ocenione przez podmioty, które je wytworzyły. Przy tym należy rozumieć, 
że wszelkie czynniki wytwarzające fakty kulturowe są właśnie czynnościami społecznymi, czyli mogą to być jednostki, grupy, a także inne działające byty społeczne. Znaniecki zauważa też, że tego typu wiedza jest niezależna od prywatnych wartościowań praktycznych danego badacza (1971, s. 299).

Co to oznacza? Kluczowe w odpowiedzi na to pytanie jest odróżnienie wiedzy praktycznej od wiedzy o charakterze naukowym. Znaniecki zauważa, że ogólny schemat tworzenia generalizacji praktycznych i naukowych ma zwykle ten sam model. Są jednak różnice, gdyż naukowcy tworzą uogólnienia oparte na o b i e k tywnych regułach logiki, praktycy natomiast „w ogóle nie myślą o zmianach jako procesach abstrakcyjnych” (ibidem, s. 268). Oznacza to, że rolą naukowca, w tym przypadku badacza kultury, jest w pierwszej kolejności dotarcie do takiego świata, jaki jawi się w świadomości badanych, a następnie na jego podstawie odbywa się budowanie abstrakcyjnego modelu zachodzącej w nim relacji. $\mathrm{Na}$ czym polega myślenie praktyczne, czyli takie, które nie powinno się znaleźć w analizie naukowej? Otóż dla praktyka klasyfikowanie faktów społecznych oznacza, że określone „czynności wiąże się z innymi wartościami” (ibidem, s. 268). Na przykład drzewo jest czymś innym dla ogrodnika, a czymś innym dla artysty, który je maluje itp. „Praktyk w ogóle nie myśli o zmianach jako procesach abstrakcyjnych" (ibidem).

Znaniecki jest uważany za antynaturalistę ontologicznego oraz naturalistę metodologicznego. Początkowo uważał on, że przedmiot badań nauk przyrodniczych różni się od przedmiotu badań nauk społecznych, jednak nie pociąga to za sobą konsekwencji metodologicznych. Rzeczywistość kulturową można badać za pomocą tych samych metod. Później jednak zmienił ten pogląd i uznał, że dla socjologa, który zajmuje się światem społecznym, kluczowa jest świadomość różnicy między przedmiotem jego badań a obszarami, które badają przedstawiciele nauk przyrodniczych.

W miarę postępu metod naukowych stawało się coraz bardziej oczywiste, iż żadnych logicznie spójnych obiektywnych generalizacji w dziedzinie kultury nie da się osiągnąć przy pomocy tego samego podejścia, jakie stosuje się w dziedzinie przyrody, tj. przez analizę i porównywanie poszczególnych faktów abstrahując od czynności tych czynników świadomych, które je tworzą i wykorzystują (ibidem, s. 269).

Badanie zjawisk kulturowych w ujęciu semiotycznym, w którym materiałem empirycznym jest tekst, przy pomocy metody hermeneutycznej, nieznane było Znanieckiemu. Skupił się on na problemie istoty nowatorskich działań twórczych i procesie ich powstawania. Dlatego też została wywiedziona koncepcja czynności twórczych i dążności twórczych. 


\section{Charakterystyka czynności oraz dążności twórczych według Znanieckiego}

Porządek, ład społeczny, opiera się na wartościach, w odróżnieniu od świata przyrodniczego, w którym wartości nie istnieją. Taki pogląd wyraził Znaniecki w Naukach o kulturze (1971). Podobne stanowisko zajął Łotman w Uniwersum umysłu (2008), który w semiosferze, będącej ludzkim odpowiednikiem biosfery świata przyrodniczego, umieścił wartości jako podstawowy wyróżnik. Czym są wartości? Mają znaczenie aksjologiczne, ontologiczne i ekonomiczne, według współczesnych podręczników do filozofii, socjologii i ekonomii. Natomiast Znaniecki lokuje wartości w człowieku twórczym, sam człowiek jest wartością. Człowiek nadaje też sens swoim działaniom. Taki sens wartości nie istnieje poza kulturą wytworzoną przez człowieka. Dlatego też badanie zjawisk kulturowych wymaga specyficznych narządzi badawczych, odmiennych od narzędzi stosowanych $\mathrm{w}$ badaniach świata przyrodniczego. Narzędzia te Znaniecki podaje i objaśnia w Naukach o kulturze.

Czynności ludzkie i dążności twórcze człowieka to pryncypialne, zasadnicze właściwości, pozwalające zmieniać rzeczywistość zgodnie z potrzebami. Bez tych dwu czynników świat ludzki nie różniłby się od świata przyrodniczego, który sam z siebie podlega niezależnym i niezmiennym prawom natury. Teoria czynności ludzkich i dążności twórczych człowieka, rozwijana przez Znanieckiego, objaśnia, jak one przebiegają i jaki jest ich cel. Teoria ta daje narzędzia do zrozumienia istoty działań ludzkich. „Czynności ludzkie dostępne są dla doświadczenia i refleksji zarówno wykonawców, jak i obserwatorów” (Znaniecki 1971, s. 322). Stąd wynika koncepcja współczynnika humanistycznego Znanieckiego.

Czynności ludzkie są przede wszystkim poczynaniami, aktywnościami, świadomymi. Można je podzielić na proste i złożone, wykonywane $\mathrm{w}$ pojedynkę lub we współpracy z innymi. Jeżeli czynność jest wykonywana zbiorowo, ma nazwę czynności społecznej. Każda świadoma czynność indywidualna czy społeczna ma początek i koniec oraz składa się z wielu faktów i związanych z nimi cząstkowych wartości. „Każda czynność ludzka jest ograniczonym dynamicznym systemem współzależnych zmiennych wartości” (ibidem, s. 322-333). Znaniecki odrzuca teleologiczne i deterministyczne teorie czynności, gdyż niemożliwe jest znalezienie pojedynczej przyczyny nawet dla elementarnej czynności. Zwykle determiniści uciekają się do zasady wielości przyczyn pośrednich, a założenia, na których opierają swoje tezy, mają charakter aprioryczny. Znaniecki uważa, że „[c]zynność w całym swoim przebiegu ujawnia stopniowe kształtowanie zamiaru w miarę tego, jak się kształtuje" (ibidem, s. 344). Końcowym efektem zamiaru jest cel, do którego zmierzamy. Proces czynności ma charakter temporalny i uwzględnia środki czy też zmiany faktów, które spowodują taką transformację rzeczywistości, aby możliwy był finalny efekt - czyli cel. Znaniecki uważa, że „[n] ie ma tu żadnej linii demarkacyjnej pomiędzy planowaniem 
czynności w myśli i jej rzeczywistym wykonaniem” (ibidem, s. 345). Jest to znaczące twierdzenie, wskazujące na ciągłość i związek myśli z działaniem. Są to dwa czynniki występujące równocześnie lub w ciągłości. Tego procesu Znaniecki dokładnie nie wyjaśnia. Proces czynności twórczych przebiega w czterech fazach czy stadiach. Pierwsza faza to zainteresowanie problemem - jest ono świadome lub nieświadome. Drugie stadium to świadome rozpoznanie problemu tkwiącego w danej czynności twórczej. Trzecia faza - wybór konkretnych metod czy narzędzi, które dają nadzieję na rozwiązanie problemu. Natomiast czwarta to nadanie adekwatnego kształtu czy postaci wytworowi technicznemu, utworowi literackiemu lub teorii naukowej. Mogą jeszcze istnieć jakieś pośrednie etapy tych czynności twórczych, lecz te - według Znanieckiego - są najistotniejsze.

Czynność twórcza wtedy ma rzeczywistą wartość, kiedy wnosi coś nowego w obszar kultury, a ta nowość musi być ważna nie tylko dla twórcy, lecz także dla innych ludzi, którzy z tej nowości materialnej lub symbolicznej mogą skorzystać bądź zrozumieć jej ideę. Podobnie jak czynności twórcze, dążności twórcze Znaniecki rozpatruje na gruncie niepsychologicznym. Odrzuca zdecydowanie teorię Freuda zawartą w Kulturze jako źródle cierpień, w której libido jako energia seksualna ma być źródłem twórczości artystycznej. Odrzuca też Pareto z teorią trzech najważniejszych pragnień i samego siebie oraz Thomasa z Chłopa polskiego i zawartą $\mathrm{w}$ tym dziele doktrynę psychologii społecznej.

Dążność twórcza jest urzeczywistnieniem zamiaru czynności [...] nie poprzedza ani nie powoduje czynności. Jest zawarta w samej czynności i ujawnia się poprzez postępującą realizację zamiaru w miarę tego, jak ów zamiar się kształtuje. Nie jest odrębnym zjawiskiem empirycznym bezpośrednio dostępnym obserwacji psychologicznej. Jej istnienie daje się tyko stwierdzić w oparciu o jej funkcję, tę zaś można odkryć obserwując zmiany realnych związków oraz ich empirycznej treści wywołanej przez podmiot czynności w miarę jej rozwoju (ibidem, s. 376).

Tak więc z psychologicznego punktu widzenia nie da się wyprowadzić żadnych uogólnień na temat dążności twórczych. Dążności twórcze i czynności twórcze są procesami nacechowanymi wysiłkiem intelektualnym i nie są procesami przyrodniczymi, lecz kulturowymi. Procesy kulturowe obejmują kontekst społeczny, w jakim jednostki są usytuowane i uwikłane. Współczesna semiologia znajduje ten kontekst, stawiając naczelne miejsce komunikacji międzyludzkiej, odbywającej się dzięki różnego rodzaju tekstom kultury, przybierającym różne postaci — od komunikatów tekstowych, przez obrazowe, do interakcji społecznych itp. W tym artykule interesuje nas tekst artystyczny, jakim są Dzienniki Gombrowicza. Stanowią one namacalny dowód wszystkich wskazanych twierdzeń.

\section{Egzemplifikacja empiryczna}

Znaniecki działania twórcze analizuje w dwóch perspektywach. Pierwsza sytuuje czynności i dążności twórcze w ogólnym systemie czynności i została schara- 
kteryzowana w założeniach teoretycznych. Druga dotyczy widzenia problemu działań twórczych z perspektywy jednostki i umożliwia empiryczną analizę.

Czynność dla Znanieckiego jest związkiem myśli i działania. Zazwyczaj w socjologii badacze skupiają się na badaniu czynności, czy ściślej mówiąc, na rejestrowaniu efektów bądź skutków czynności poprzez wywiady czy obserwacje, natomiast sfera myśli w tym wypadku jest wyłączona z przedmiotu zainteresowania socjologa. Główną tego przyczyną jest brak intersubiektywnej komunikowalności i sprawdzalności. Socjologia normatywna wprowadza pojęcie sfery deklaratywnej i sfery praktycznej, i tym samym neguje istnienie takiego związku, który akcentuje współczynnik humanistyczny. W tym artykule nie neguje się tego stwierdzenia, lecz warto zwrócić uwagę, że Znaniecki wyraźnie zaznacza, iż socjologia powinna zajmować się tylko niektórymi związkami między wartościami i czynnościami. Do tego obszaru należy działalność twórcza, która charakteryzuje się silnym związkiem myśli i działania. Możemy dla celów analitycznych posłużyć się Dziennikiem Gombrowicza i potraktować go właśnie jako zapis tych związków.

Znaniecki uznał za twórczą taką działalność, która wnosi do kultury coś nowego, zmienia i przekształca świat społeczny, a społeczność uzna tę zmianę za niezbędną lub pożyteczną. W dziedzinie literatury, którą się tu posłużymy, może być to nowatorstwo formalne lub ideowe. Gombrowicz zasłużył się szczególnie w nowatorstwie ideowym, ale ma też osiągnięcia w nowatorstwie formalnym. Jak dochodził do nowatorstwa ideowego, pokazują jego Dzienniki, w których zajmuje się różnego rodzaju problemami filozoficznymi. Problemy te ujmował w niewielkich rozmiarów esejach. Dotyczyły one np. śmierci, młodości, języka, bycia artystą, Kościoła katolickiego, patriotyzmu, komunizmu. Wyrażał poglądy odkrywcze, wykazując szerokie zainteresowania filozoficzne i społeczne, w tym socjologiczne. Objaśniał też czytelnikom znaczenie swojej twórczości, gdyż w tej kwestii współcześni mu krytycy literaccy zawiedli. Jego słynna „gęba” i „pupa” przeniknęły już do mowy potocznej, ilustrując konwencjonalne zachowania społeczne. Gombrowicz miał więc wpływ na ośmieszanie i burzenie niektórych stereotypowych zachowań społecznych, gdyż chciał ujrzeć prawdziwego człowieka, a nie za zasłoną konwencji. Tak Gombrowicz ilustruje stereotypy zachowań w interakcjach społecznych, zburzone w Ferdydurke (1986b):

W Ferdydurke człowiek jest stwarzany przez ludzi. Ale rozumieją to [czytelnicy?] przede wszystkim jako uzależnienie człowieka od grupy społecznej, która narzuca mu obyczaj, konwenans, styl [...] I nawet zdarza się im w tym punkcie nadmienić, iż jest to prawda zgoła banalna, truizm i wywalanie otwartych drzwi.

Jednego wszakże nie dostrzegli. Mianowicie, iż ten proces urabiania człowieka przez ludzi jest w Ferdydurke pojęty nieskończenie szerzej. Nie przeczę, że istnieje zależność jednostki od środowiska - ale dla mnie o wiele ważniejsze, artystycznie bardziej twórcze, psychologicznie bardziej przepaściste, filozoficznie bardziej niepokojące jest to, że człowiek jest stwarzany także przez pojedynczego człowieka, przez inną osobę. W przypadkowym zetknięciu. W każdej chwili. Mocą tego, że ja jestem zawsze „dla innego”, obliczony na cudze widzenie, mogący istnieć 
w sposób określony tylko dla kogoś i przez kogoś, egzystujący — jako forma — poprzez innego. A więc nie idzie tylko o to, że mnie środowisko narzuca konwenans, lub mówiąc za Marksem, że człowiek jest produktem swojej klasy socjalnej, a o zobrazowanie zetknięcia człowieka z człowiekiem w całej jego przypadkowości, bezpośredniości, dzikości, o wykazanie, jak z tych przypadkowych związków rodzi się Forma - i często najbardziej nieprzewidywalna, absurdalna. Gdyż ja sam dla siebie nie potrzebuję formy, ona jest mi potrzebna po to tylko, aby ten drugi mógł mnie zobaczyć, odczuć, doznać. Czyż nie widzicie, że taka Forma to coś o wiele potężniejszego, niż zwykły konwenans społeczny? I że to żywioł nie do opanowania? Póki rozumiecie Ferdydurke jako walkę z konwenansem, ona spokojnie będzie kłusowała po utartej ścieżce; ale gdy pojmiecie, że tu człowiek stwarza się z drugim człowiekiem w sensie najdzikszego bodaj wyuzdania, ona zarży i da susa, jak spięta ostrogą, ponosząc was w dziedzinę Nieobliczalnego. Ferdydurke to o wiele bardziej forma-żywioł, niż forma-konwenans.

Oni mówią dalej, że ja w Ferdydurke (i w innych utworach) walczę z fałszem, z zakłamaniem [...] Zapewne. Ale czyż nie jest to znowu uproszczenie mego człowieka i moich intencji?

Przecież mój człowiek jest stwarzany od zewnątrz, czyli z istoty swojej nieautentyczny — będący zawsze nie sobą, gdyż określa go forma, która rodzi się między ludźmi. Jego „ja” jest mu zatem wyznaczone w owej „międzyludzkości”. Wieczysty aktor, ale aktor naturalny, ponieważ sztuczność jest mu wrodzona, ona stanowi jego cechę człowieczeństwa - być człowiekiem to znaczy być aktorem - być człowiekiem to znaczy udawać człowieka - być człowiekiem to „zachowywać się" jak człowiek, nie będąc nim w samej głębi - być człowiekiem to recytować społeczeństwo. Więc w tych warunkach jakże może rozumieć walkę z gębą, z miną, w Ferdydurke? Przecież nie tak, że człowiek ma się pozbyć swojej maski — gdy poza nią nie ma żadnej twarzy — tu tylko można żądać, aby uprzytomnił sobie swoją sztuczność i ją wyznał. Jeśli jestem skazany na fałsz, jedyna szczerość mi dostępna polega na wyznaniu, że szczerość jest mi niedostępna. Jeśli nigdy nie mogę być całkowicie sobą, jedyne co mi pozwala uratować od zagłady moją osobowość, to sama wola autentyczności, owo uparte wbrew wszystkiemu „ja chcę być sobą”, które jest niczym więcej jak tylko buntem tragicznym i beznadziejnym przeciw deformacji. Nie mogę być sobą, a jednak chcę być sobą i muszę być sobą - oto antynomia, z tych nie dających się uładzić [...] i nie oczekujcie ode mnie lekarstw na nieuleczalne choroby. Ferdydurke stwierdza jedynie to wewnętrzne rozdarcie człowieka — nic więcej (s. 8).

Tekst ten jest związany ideowo z minionym stuleciem, kiedy forma decydowała o stosunkach międzyludzkich i była balastem, spod którego ukryte prawdziwe ja, indywiduum, pragnęło się uwolnić i pokazać innym w całej okazałości. Dramat formy dostrzegamy również obecnie, gdy człowiek nie potrafi dostosować swego zachowania do konwencji obowiązującej w środowisku, w którym żyje, gdy nie potrafi znaleźć odpowiedniego stylu w zachowaniu, ubiorze, mowie, a jego otoczenie społeczne daje mu to do zrozumienia, wykluczając z gry towarzyskiej, np. w szkole czy miejscu pracy. Sytuacja ta jest odwrotnością Gombrowiczowskiego łamania form dla podkreślenia niezależności indywiduum wobec otoczenia. Brak formy stał się obecnie zjawiskiem dominującym w życiu społecznym. Nastąpiło przesunięcie wagi znaczenia formy. Niekowencjonalny strój lub zachowanie nie budzi często sprzeciwu, ale interesuje, a nawet zachwyca. W dzisiejszych czasach łatwo łamać formy i nie ponosić za to konsekwencji.

Ideowe nowatorstwo Ferdydurke zawiera się w postawieniu pytania, w jaki sposób wyzwolić się od maski, którą narzuca nam każdy napotkany człowiek, 
aby umieścić nas w swoim wyobrażeniu sytuacji. Forma zachowań, przyjęta w danej epoce, oswaja ludzkie emocje i chroni przed agresją czy też „dzikością”, jak nazywa to Gombrowicz, ale zamyka przed nami prawdę o człowieku, fałszuje jego intencje i w rezultacie nie wiemy, co nasz interlokutor rzeczywiście myśli. W ten sposób obracamy się w kręgu nieprawdziwych intuicji i mamy skrzywiony obraz sytuacji. Przebywanie $w$ takim środowisku staje się dramatem nieporozumień. $\mathrm{Z}$ drugiej strony forma jest naczelną kategorią kulturową i bez niej kultura zamienia się w nie-kulturę, więc w tym miejscu można polemizować z Gombrowiczem i jego pragnieniem wyzbycia się formy. Świat formy decyduje o swoistej harmonii społecznej, niezbędnej w utrzymaniu ładu społecznego. Dzięki kostiumowi formy czujemy się bezpieczni, gdyż ten zapewni nam przewidywalność sytuacji. Nowatorstwo Gombrowicza w literaturze polega na tym, że uczynił samą formę centrum dramatu, a to pociągnęło za sobą nowatorstwo formalne. Pytanie, czy zwalczać formę, czy też ją popierać, pozostawiamy otwarte.

Egzemplifikacja czynności i dążności twórczych, zdefiniowanych przez Znanieckiego, potwierdza ich istnienie $\mathrm{w}$ zdaniach wypowiedzianych przez Gombrowicza w Dziennikach. Oto niektóre cytaty potwierdzające tę tezę:

Historia mego stawania się to dzieje ciągłego przystosowywania się mego do mych dzieł literackich — które zawsze zaskakiwały mnie rodząc się w sposób nieprzewidziany, jakby nie ze mnie [...] Do pewnego stopnia książki moje wynikają z mego życia — ale w większej mierze życie urobiło mi się z nich i z nimi (Gombrowicz 1986a, s. 18).

Dążności twórcze mają związek z życiem artysty, które uwikłane w kontekst kulturowy epoki, wyraża jego klimat w literaturze, ale też dzieła artystyczne mają wpływ na ich twórcę, uwzględniając ich nie w pełni świadomą realizację. Tu kryje się tajemnica, w tych nieświadomych czynnikach, zmuszających artystę do nadania określonego kształtu dziełu. Tajemnicę tworzenia starożytni wiązali z pomocą bóstw czy muz, do których w inwokacjach zwracali o pomoc. Do dziś wyjaśnienie tajemnicy tworzenia dzieł pozostaje otwarte. „Sztuka prawdziwie ambitna [...] musi wyprzedzać swój czas, być sztuką jutra [...] musi być burzycielką dzisiejszych pojęć w imię pojęć nadchodzących" (Gombrowicz 1986a, s. 31). Tutaj z kolei pisarz rzeczywiście potwierdza pogląd Znanieckiego o wartości nowatorstwa, a nawet idzie dalej - przewidywanie przyszłości niejednokrotnie przydarza się twórcom-wizjonerom.

Jego teza o dominacji młodości w życiu przyszłych pokoleń potwierdziła się. Starość nie budzi już szacunku jak niegdyś, jest ciężarem dla młodego pokolenia. Kult młodości przejawia się obecnie w modzie, sporcie, zainteresowaniach kulturą. Te dziedziny życia są wspólne wszystkim kategoriom wiekowym.

„Wartość czystej sztuki polega na tym, że ona rozbija schematy” (Gombrowicz 1986a, s. 31). A schematy są zaporą przed dążeniem do zmiany, która jest niezbędna, aby społeczeństwo, czy szerzej system społeczny, mogły istnieć.

Stosunek Gombrowicza do współczesnej nauki jest interesującym przykładem krytyki myśliciela obserwatora, usytuowanego na zewnątrz pola nauki, 
jakby powiedział Bourdieu (2008). Jego krytyka myśli Foucaulta jest druzgocąca: „Foucault zamierza unicestwić człowieka w episteme. Ale po co? By utwierdzić się w swej osobowości, wygrać bitwę z innymi filozofami, stać się znakomitością" (Gombrowicz 1992, s. 173). Z drugiej strony „Foucault ma ze swego punktu widzenia rację zapowiadając zmierzch człowieka, jego stopniową likwidację. Tak, człowiek znika, ale wyłącznie jemu, Foucault, w ściśle określonym polu jego teorii" (ibidem). Jest to optymistyczne stwierdzenie, które Gombrowiczowi, jako artyście, a szerzej humaniście, pozwala nadać sens kondycji człowieka w odróżnieniu od Foucaulta, który mu ten sens odbiera.

Podobnie krytyczny stosunek ma Gombrowicz do strukturalistycznej koncepcji nauki. „[W] strukturalizmie człowiek przestał działać i jest tylko przedmiotem działania, przestał mówić i jest tylko wypowiedziany" (ibidem, s. 170). Taki punkt widzenia, czyniący człowieka ograniczonego przez struktury, stwarza go bierną marionetką, gdyż jest przedmiotem działania, przestał mówić, gdyż słowa mówią za niego. Gombrowicz, zastępując strukturę formą, widzi w swojej twórczości podobne konsekwencje, lecz dodaje, że forma tworzy się głównie w sferze międzyludzkiej, w każdym momencie człowiek jest stwarzany przez innych ludzi. Strukturaliści szukają swych struktur w teorii kultury, natomiast Gombrowicz, jak sam mówi, znajduje je w bezpośredniej rzeczywistości.

W tym miejscu moglibyśmy wtórować Gombrowiczowi, nawiązując do semiotycznej koncepcji Łotmana i jego rozumienia komunikacji w semiosferze, która jest nieustannym tworzeniem nowych sensów i działań ludzkich, dzięki binarności i asymetrii złożonych porządków, wzajemnie poprzecinanych, wchodzących w skład przestrzeni semiotycznej (Łotman 2008). Tak więc strukturalizm przedstawia się nam tu jako zamknięty, złożony labirynt zjawisk kulturowych.

Poglądy Znanieckiego są bliższe Gombrowiczowi ze względu na podobną interpretację dążności twórczych, które przejawiają się w woli wyrażenia przez artystę swojej wizji rzeczywistości objaśniającej odbiorcom, jak działa i funkcjonuje świat społeczny. Pisarz odkrywa przed czytelnikami taki obraz świata, który jest równoległy do obrazu świata przekazywanego przez naukę, a zdarza się, że nawet jego obserwacje wyprzedzają ją.

\section{Podsumowanie}

Koncepcja czynności i dążności twórczych Znanieckiego posłużyła w tym artykule do próby wyjaśnienia procesu twórczego, który jest nierozstrzygnięty przez naukę. Aspekty psychologiczne zostały przez Znanieckiego odrzucone jako niespełniające postulatu naukowości. Dzienniki Gombrowicza posłużyły jako materiał empiryczny, umożliwiający uzasadnienie tezy Znanieckiego o związku myśli i działania jako najważniejszych czynników w procesie twórczym. 
Metoda hermeneutyczna zastosowana w tym artykule w kształcie nadanym mu przez Diltheya polega na wyeksponowaniu dwóch kategorii - rozumienia i wyjaśniania (Przyłębski 2016, s. 32). W słynnym zdaniu „[n]aturę wyjaśniamy, życie psychiczne zaś rozumiemy" (ibidem) przeciwstawił on dwa sposoby uprawiania nauki. Nauki przyrodnicze wykorzystują wyjaśnianie praw natury, a nauki humanistyczne, w tym społeczne, stosują rozumienie dla oceny wartości, celu, i sensu wytworów myśli ludzkiej. W naukach humanistycznych współpracują z sobą metoda porównawcza, analogii i indukcji. Dzięki nim proces rozumienia pogłębia się. Termin „interpretacja” stosuje się, gdy bezpośrednie, natychmiastowe zrozumienie nie jest dane i wymaga pogłębionej analizy. Rozumienie i wyjaśnianie to dwie fazy tego samego procesu hermeneutycznego, dzięki któremu odsłania się prawda o zjawiskach wewnętrznych i zewnętrznych, dotyczących indywiduum. Metoda hermeneutyczna była rozwijana przez Ricouera, Heideggera, Gadamera i innych, i w dalszym ciągu znajduje się w kręgu zainteresowań filozofów współczesnych w Polsce oraz na zachodzie Europy. Na szczególną uwagę zasługuje praca Gadamera Prawda i metoda, gdzie pada zdanie „Kto ma język, ten ma świat" (Gadamer 1993, s. 368). Oprócz kategorii rozumienia i wyjaśniania metoda hermeneutyczna uwzględnia narzędzie, jakim jest język. Rola języka odgrywana jest w komunikacji międzyludzkiej i nadaje sens rozumieniu i wyjaśnianiu.

\section{Bibliografia}

Boudon R. (2009), Logika działania społecznego. Wstęp do analizy socjologicznej, przeł. K. Kowalski. Bourdieu P. (2009), Reguty sztuki. Geneza i struktura pola literackiego, przeł. A. Zawadzki, Kraków 2009. Gadamer H.G. (1993), Prawda i metoda. Zarys hermeneutyki filozoficznej, przeł. B. Baran, Kraków. Gombrowicz W. (1986a), Dziennik 1953-1956, Kraków-Wrocław.

Gombrowicz W. (1986b), Dziennik 1957-1961, Kraków-Wrocław.

Gombrowicz W. (1992), Dziennik 1967-1969, Kraków.

Łotman J. (2008), Uniwersum umysłu, przeł. B. Żylko, Gdańsk.

Przyłębski A. (2016), Krytyka hermetycznego rozumu. Preliminaria, Kraków.

Szacki J. (1986), Znaniecki, Warszawa.

Znaniecki F. (1971), Nauki o kulturze, Warszawa.

Znaniecki F. (2008), Metoda socjologii, Warszawa.

Forum Socjologiczne 7, 2016

(C) for this edition by CNS 


\section{How to study the culture texts according to Znaniecki. Relation between creative activities and creative tendencies and values}

\section{Summary}

The aim of this article is to consider that consideration of artistic creation as an action considering some special aspects of human activity. This activity is suitable for analysis using the notion of creative activities and creative tendencies and its relation to values. The process of writing is unbreakable connection between the thought and the action. The mystery of creative process is defined as non psychological but related to the mechanisms of social systems. To illustrate this we chose Gombrowicz diaries as an example on account because of their formal and inventive improvements. 